\title{
The Factors Affecting Bank's CSR Expenditures: Evidence from Bangladesh
}

\author{
Niluthpaul Sarker ${ }^{1}$ and Kazi Md. Nasir Uddin ${ }^{2}$
}

\begin{abstract}
Corporate social responsibility is a philanthropic activity that works for the development of underprivileged people in society. The study examined the factors that are considered as influential stimuli of CSR expenditures.

Prais Winsten regression model is applied to a sample of 32 commercial banks from the year of 2011 to 2015 with 160 observations. The study revealed that bank size and one year lag of CSR expenditure positively affect CSR expenditure and are statistically significant. However, bank default risk, shareholders influence, and bank age have a negative and significant effect on CSR expenditures of banks. Therefore, the study's implication is to address the factors properly for the country's socio-economic development.
\end{abstract}

JEL classification numbers: $\mathrm{C} 12, \mathrm{C} 23$.

Keywords: CSR, Quantitative Methods, Panel data, Banks, Bangladesh.

\footnotetext{
1 Associate Professor, Department of Accounting \& Information Systems, Jagannath University, Dhaka-1100, Bangladesh.

2 Associate Professor, Department of Accounting \& Information Systems, Jagannath University, Dhaka-1100, Bangladesh.
} 


\section{Introduction}

The overall economic development of the country essentially depends on the banking sector. Modern commercial banks play an important role in economic growth as well as social growth. Nowadays, the concept of Corporate Social Responsibility (CSR) quickly increases constructively. Earning the highest level of trust requires the balanced provision of value to four constituents: customer, shareholders, market environment \& society and employees. Through this process, the bank is responsible for the sustainable development of society and fulfils corporate social responsibility (CSR). To achieve greater social goals, banks have taken various initiatives in different fields. In order to strengthen CSR activities, the bank focused on employment, education, sports and cultural activities and disaster relief materials.

In the last few decades, the rapid dynamism of globalization has added new dimensions to the concept of social responsibility in the context of the market economy. In the banking sector, especially in the private sector, significant progress and significant market share growth have been achieved. Understanding the current situation, especially commercial banks, are trying to increase their social responsibility to build a vibrant society. Enrich the productivity of the nation through their social investment education, employment generation, poverty alleviation, and transparency.

The latest theories of CSR (Baron (2001), McWilliams and Siegel (2001), Bagnoli and Watts (2003)) said that companies participate in the "profit-max" CSR. That is, companies are considered to be socially responsible because they expect a benefit from this action. Barnea and Rubin (2010) found that the decision to invest in CSR related to insider ownership negatively, and an overinvestment hypothesis explains the findings in light of this result. CSR is good for the price of a specific level of the shareholder, but internally may be interested in overinvesting in it to improve their reputation and do so if their ownership is low.

CSR's sustainable development is a voluntary contribution by a company that goes beyond legal requirements (Gamerschlag et al., 2010). During the last ten years, there has been growing public awareness of role in society and the corporation's responsibility (Hackston \& Milne, 1996). While the company is credited with contributing to economic and technological advances, they have also been criticized for creating social problems. Therefore, the company is engaged in CSR activities and started publishing related to this program. Currently many great and old companies are concerned about efforts and money, contributing and publishing a great deal of information on the performance of their CSRs in the investment industry sector (Gray et al., 2001; Gray et, 1995; Hackston \& Milne; 1996; McGuire et al., 1990; Waddock \& Graves,1997). For example, companies in the oil sector, where environmental issues are more focused on: and, on the other hand, Food products are associated with community, health, and food-related CSR activities. Corporate social responsibility (CSR) practices are a relatively new phenomenon emerging in developing countries (Utting, 2002: 135-158). However, CSR's 
concept is not new to most developing countries because most of it is a long-term tradition in which business is expected to meet specific social obligations (Blowfield and Frynas, 2005:499-513). Most of the existing research related to corporate social reporting focuses on North America's industrialized nations and Western Europe (Gray et al., 1986; Guthrie and Parker, 1990). The amount of experimental research on corporate social responsibility is not enough, and poor in developing countries, such as Bangladesh, it is unfortunate that although it is widely used internationally, its response lacks Bangladesh. CSR practices in Bangladesh would be a severe step to ensure rapid industrialization and access to global markets and corporate governance, labour rights, workplace safety, and fair treatment of workers, community development, and environmental management. With the aim of developing CSR method, the Bangladesh Bank has issued notices on promoting CSR system for banks and non-bank financial institutions. Similarly, banks are already involved with CSR activities and are using their annual reports to promote their policies and activities in targeted areas, including government policies, environmental protection, social investment, and other achievements. Therefore, for the needs of the time, situation and interested groups; banks and financial institutions are required to publish their social responsibility activities in their annual report.

The banking sector plays a central role in every economy. This sector storages deposits, distribution of loans for people and businesses, make it possible for their investment. Besides, banks manage payments and manage securities transactions and individuals and institutions for maximum savings and investment. Besides, the banking industry is also a major employer; the industry is, in fact, unique to create employment. It is a process by which the country's most profitable and effective sectors are directed to the most productive sources for regular and future growth. Like other developing countries, the banking sector of Bangladesh is one of the most influential factors in the economy as well as its financial sector. But the banking sector is not yet strong enough to be launched for its weakening strategy; most banks are urban-based (except few; like - Grameen Bank). As a result, a portion of the population (about 70\%) is still deprived of banking services' benefits. Then, most banks gain profit and rarely have concerns about society. As a responsible entity of society, when every organization should be worried about society, quite a few numbers of the organizations/banks are concerned even their attention is mostly limited to providing some sort of financial help; like-scholarship to the poor but meritorious students. However, it has agreed that financial development is a prerequisite for economic growth and, thus, for a country's development. With the growth of the population, Bangladesh needs a socially responsible and transparent financial system (such as the banking sector), increasing domestic and national savings and investment, creating more employment opportunities, and ensuring higher economic growth. Therefore, the need for a responsible banking system that the maximum population can access facilitates the growth of the economy and can contribute significantly to Bangladesh's development. 


\section{Purpose of the Study}

The study's primary objective is to investigate the proximate causes that influence CSR investment in society. This study's focus group in the banking sector plays a vital role in socio-economic development.

However, it is remarked as a philanthropic activity nowadays it mandatorily imposed by the regulatory bodies.

The core objectives will also serve some of the specific objectives incorporated in the study. It will focus:

a) The CSR investment trends over the period.

b) The sectoral composition of CSR expenditures by banks within the years; and

c) The priority of investments in the social perspectives.

\section{The theoretical background of Corporate Social Responsi- bilities (CSR)}

CSR refers that organizations consider society's interests by taking responsibility for the impact of their activities on customers, suppliers, employees, shareholders, communities, future generation and environment. Corporate Social Responsibility (CSR) is the responsibilities of an organization to proactively promote the public interest by encouraging community growth and voluntarily eliminating practices that harm the public interests. It is the deliberate inclusion of public interest into corporate decision-making. Broadly, CSR activities of an organization should embrace honoring the three P's-People, Planet and Profit. CSR policy would function as an automated mechanism, where business would ensure adherence to laws \& ethical norms.

With the passage of time, it is found that the concept of CSR triggers out in an extensive form from the very rigid laxity. In the earlier stage, businessman counts the profit-generating activities as their main focus ignoring the social consequences. However, the civilized society develops the welfare theories that dragged down from self-interest theory.

Figure 1 below showed the CSR models in four perspectives generated by the practice and in theory. These are an Ethical model, Statist model, Liberal model, and Stakeholder model. In the ethical model, CSR is considered as corporate philanthropy that was the pioneer of Cadbury Brothers in England and the TATA Family in India. This sentiment greatly evolved in the $19^{\text {th }}$ century and eventually spread over with the rhythm of social development. It is also notable that Mahatma Gandhi was the propagator who took an active role in spread over the sentiment in the business world for socio-economic development. 


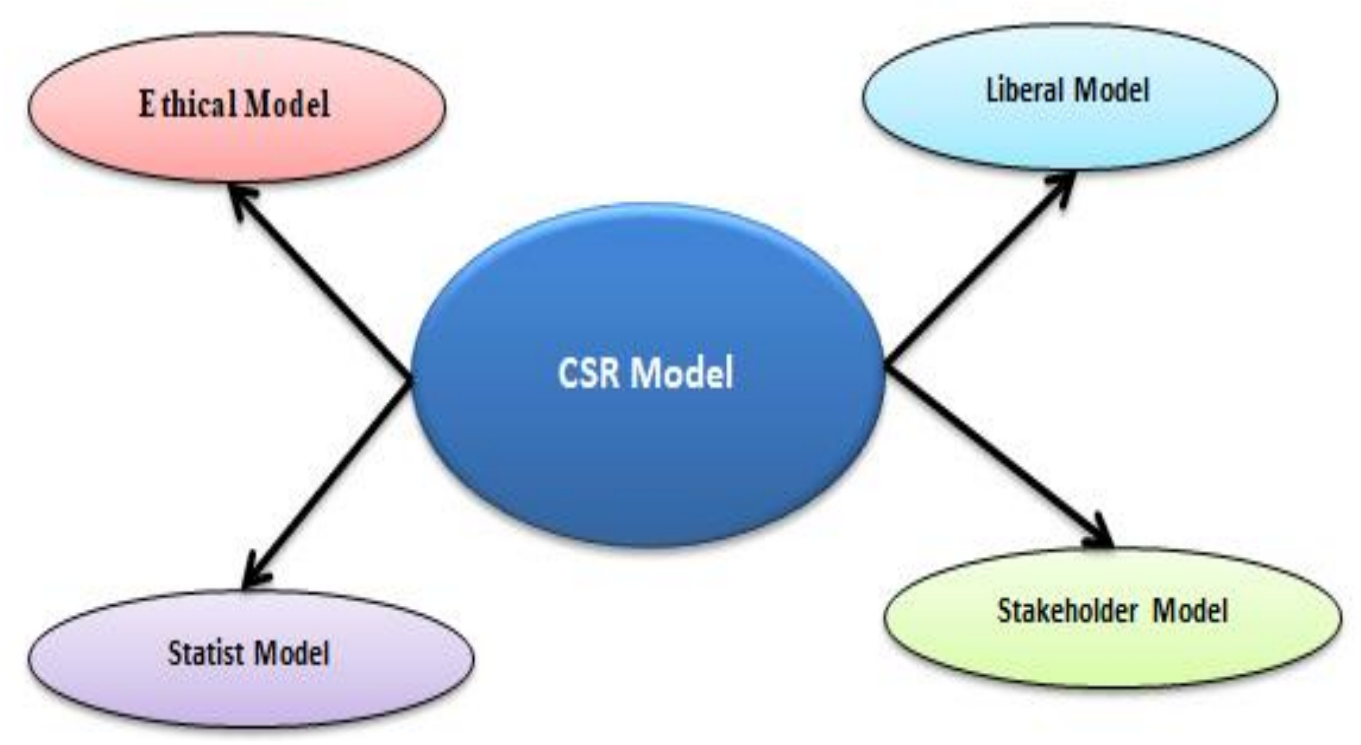

Figure 1: Models of CSR

The Statist model was evolved based on socialist ideology and directly connected with "state leadership." The concept urge for the nationalization of industries where the motive was to serve the society for their well-being. In this perspective, social welfare was considered the sole responsibility of the leaders who took action based on equal distribution of resources among the people. However, the liberal model was based on the philosophy of Milton Friedman in 1958. This model stated that companies are entirely obligated to their owners. The idea was based on the shareholders model that stimulate for profit maximization. The doctrine of liberal model holds that business is operated for the motive of profit and it's enough to obey the laws prevailed in the society. They assumed that taxation and private charities are the boundaries of social contribution for business.

Lastly, the stakeholder model emerged in society as a sentiment where the concerned entities were considered a stair of sustainability. R. Edward Freeman proposed the model in 1984. According to Freeman (1984), a stakeholder is an individual or a group of persons affected by an organization's activities where the firm's main objective is value or wealth maximization (Harrison \& Wicks, 2013). Shareholders are the organization's representatives and the labour firm, academia, church, indigenous peoples, human rights groups, government legislative bodies, etc. On the other hand, shareholders are also the customers because they decide their utility functions based on individual predilections by themselves. Their preferences to come out of a sense of transactions, relationships, and strong interactions with their utility affect that utility they receive (Harrison \& Wicks, 2013).

Freeman (1984), who is the founder of shareholder theory, depicts that the business and executives who manage the organization should do or create value for the community like customers, suppliers, employees, investors (or shareholders) (Kent $\&$ Chan, 2003). The objectives of the organization can be achieved by balancing the 
conflicting interests of the shareholders. Therefore, it is the organisation's responsibility to take care of the assets of the shareholder subject to risk from the organisation's activities (Capasso, 2004). However, advocates of this theory given shareholders who owned the firms are to create the firm's maximum value; the value is the combination of all the other stakeholders that are made for (Arora, 2010).

\section{CSR Expenditures by the Banking sector of Bangladesh}

Commercial banks are becoming conscious of their responsibilities towards society; their contributions to society in monetary terms are also increasing day by day. After the issuance of Bangladesh Bank guidance (DOS Circular No 01 Dated 1st June 2008) regarding the commercial banks' corporate responsibilities, engagements of banks in CSR initiatives are increasing regarding direct monetary expenditures over the passage of time.

Now CSR expenditures of banks have been largely far in the form of passive grants and donations. Apart from one-off grants and giveaways, some banks have engaged themselves in longer-term continuing support commitments, especially in education and healthcare. Besides the passive arrangements by way of grants/donations, banks are now getting actively engaged in socially responsible business operations, increasing lending to under-served economic sectors like agriculture and SMEs, towards fuller financial inclusion and faster poverty eradication.

CSR is relatively a new concept in the service industry of Bangladesh. Especially up to the nineties, the concept was not widely used in, except in a few organizations, but it was mostly limited to giving some sort of material help upon an inevitable factor disaster; like flood, cyclone, winter, etc. However, after the nineties, with the revolution of private commercial banks, CSR's concept takes huge attention of the scholars, researchers, and many other stakeholder groups. Nowadays, the concept of CSR has become a big concern in the banking industry, and almost every bank seems to practice it as well as to take it as part of their operational strategy.

As a responsible corporate entity, it has identified education, environment, health, culture \& heritage, and other forms of social activities. Though they have focused on the major concerns (People, Planet and Profit and the four steps of Caroll's pyramid), it is quite insignificant. In fact, both the banks have focused on society's major concerns, but they all need to focus more broadly.

Chart 1 below represents the pattern of CSR expenditure in the pre-defined segments. The chart shows that in 2014, there was the highest amount of spending on the education sector, followed by Disaster relief funds. On the other hand, the banking sector has spent the third-highest amount in the health sector, which is $21 \%$ of their investments. At this point, the study reveals that the expenditure on health issues and in the education sector increases over the years, whereas the amount of spending on all other segments fluctuates during this time through a significant amount has been spent for disaster relief. 


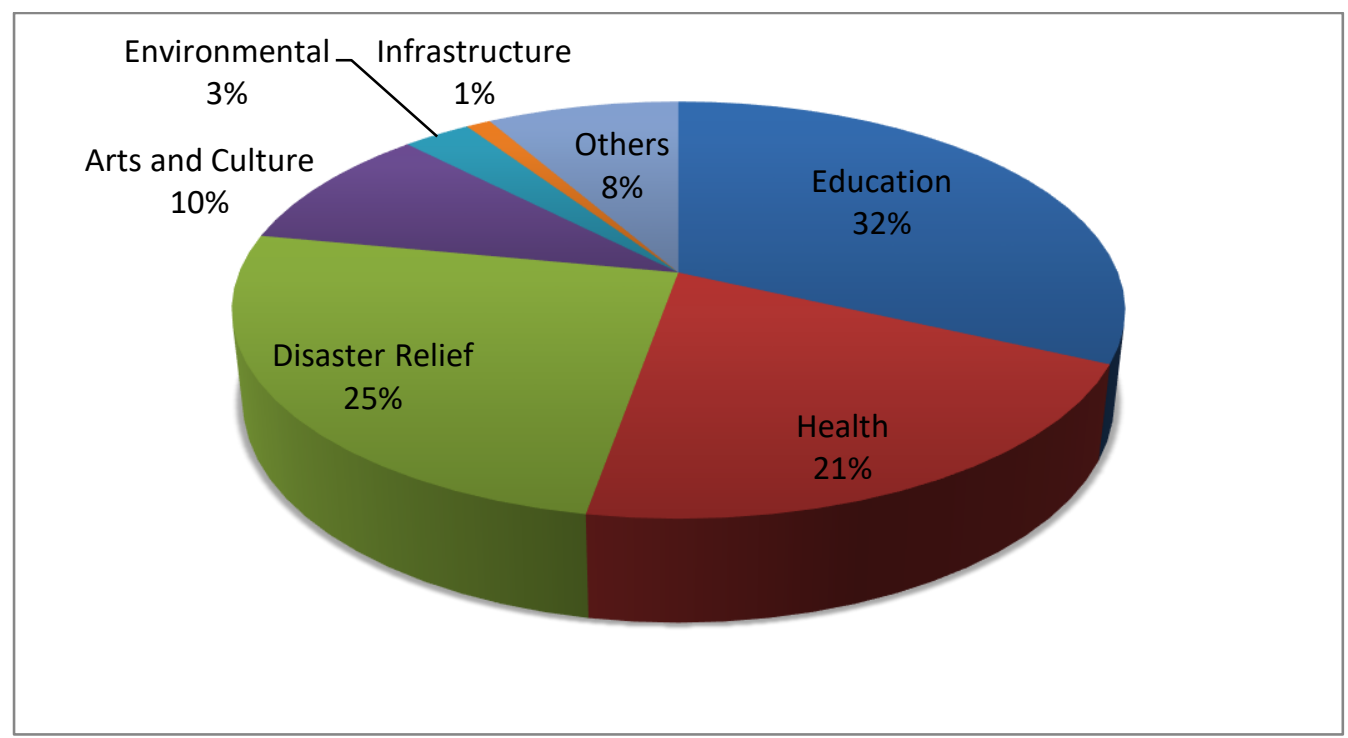

Chat 1: CSR expenditure by segments

Chart 2 below showed the CSR expenditure on the education sector by the commercial banks of Bangladesh. It is found that more than $40 \%$ of banks donated their funds to the education sector ranges from $0 \%$ to $5 \%$. Furthermore, more than $20 \%$ of banks invested their funds in more than $30 \%$ of their investment. The remaining $33 \%$ of banks invested their fund between $6 \%$ to $30 \%$ of their total CSR investment. As a developing country, the business organization should invest more in the education sector to produce a more skilled workforce for society.

\section{Chart 2: CSR Expenditure on Education Sector}

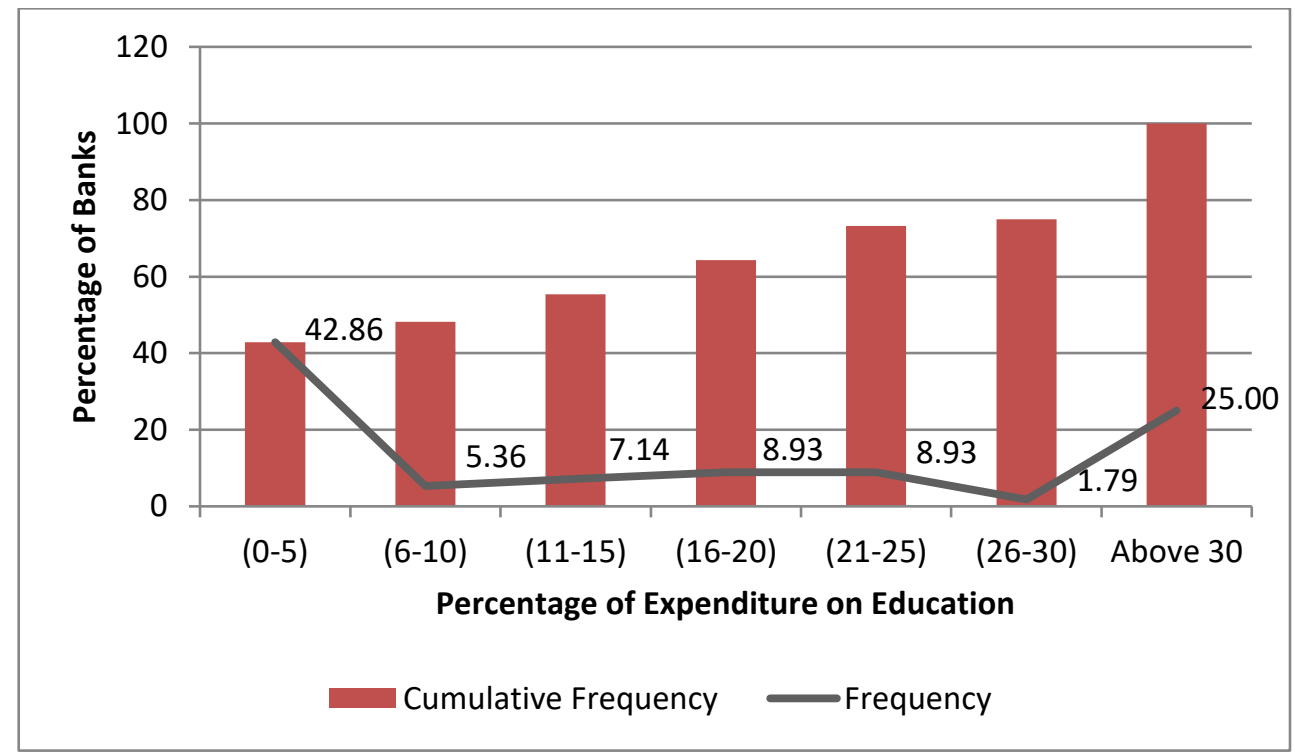


Chart 3 below showed that almost $50 \%$ of the banks donated their funds to health sectors from $0 \%$ to $5 \%$. It is also noted that $20 \%$ of banks contributed more than $20 \%$ to society's health-related issues. Therefore, the remaining $30 \%$ of banks belong to the group from $6 \%$ to $20 \%$ and less in higher rates. It indicates that most of the banks invested their funds in health issues, but the amount is not remarkable in any sense.

Chart 3: CSR Expenditure on Health Sector

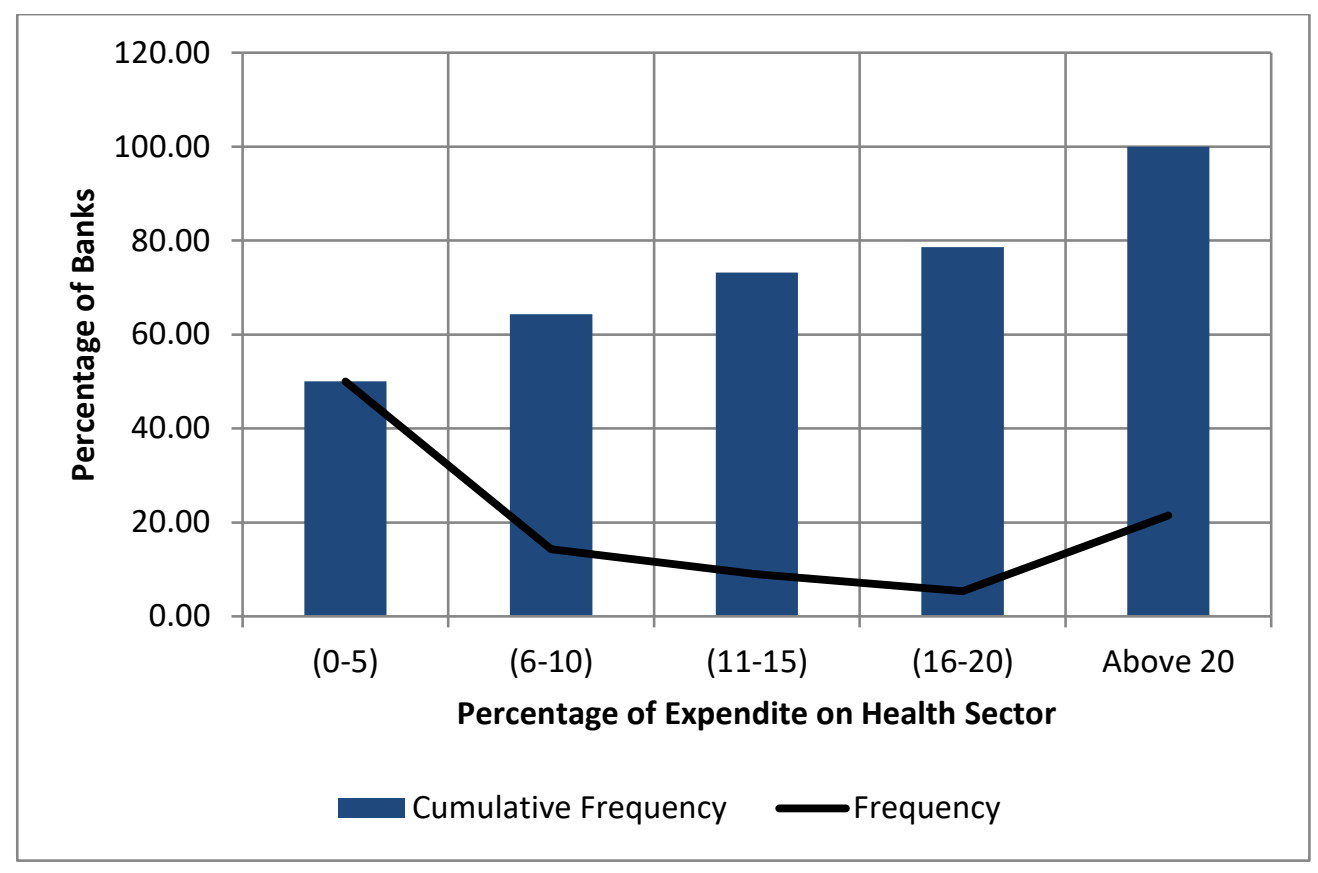

\section{Literature Review}

Investors have a growing tendency towards directing their money toward socially responsible organizations. The World Business Council for Sustainable Development (WBCSD) has defined CSR in the following way: "CSR contributes to sustainable economic development, working with workers, their families, with local community and society in general for improving the living standards".

This definition exposes the CSR area in four parts:

i) Workplace (work together with the staff)

ii) Marketplace (contact with the customer)

iii) Community (local communities and society)

iv) Environment (natural environment).

As corporate citizens, commercial banks are committed to working for workers, local communities, and society, for employees, for better business and development, their livelihood, and sustainable economic development. The evidence is that 44 out of 48 commercial banks are engaged in CSR activities.

According to Peter A. Heslin and Jenna D. Ochoa (2008) "United States" green mutual fund investment rose to $69.5 \%$ in the last six years. In the previous three 
years, the total amount of money invested in clean energy has reached the global level of $\$ 70.9$ billion." The primary goal of any economy is to maximize the economic resource (Adam Smith), Production and distribution (John Stuart Mill), wealth resources and material welfare (Alfred Marshall), unexpected money (Lionel Robbins) to increase satisfaction with the people's needs. But now a day, a strong motive is not only consistent with those scholars but also social, moral and environmental concerns. Therefore, the main objective, purpose or use, for which the organizations exist, to ensure the living conditions of mankind and sustenance of the Earth containing mankind.

Some authors argue that the concept of accountability should be expanded in stakeholder's view of CSR.

Drawing from the work of other educators (such as Gray et al. 1987; Williams 1987; Roberts and Scapens, 1985), Swift (2001:17) describes the extent of responsibility as "... the need to provide an account or support, because of which one is qualified narrowly as "... only relevant to the contractual system ... where accountability is not contractually bound there can be no act of accountability".

Considered by Konz and Ryan (1999:200): "People are searching for money in the work that crosses the only economic exchange between isolated, autonomous people ... (and) ... their way of living with their spiritual life, To work together with the community, a dream and purpose that goes without earning money alone ". In modern times, business activities around society are undergoing visible development. This is not just a promotional activity but an ethical dilemma.

Major corporate moral disadvantages affecting the environment, human resources and community, Public welfare agencies voluntarily increased their corporate social responsibility (CSR) programs to disclose to stakeholders. As a result, corporate social responsibility has become a significant business world. Besides, the CSRD is an extension of the financial disclosure system that reflects society's wider expectation related to the business community's role in the economy. Besides, CSR's role is being discussed in an international sector (Van der Laan Smith, Adhikari, and Todar, 2005), with the rapid collapse of cross-border economic barriers and globalization of business. The World Business Council for Sustainable Development (WBCSD) (1998, p. 3) defines CSR as Continually commitment by business, contributes to mortality and economic development, and improves the quality of living of the workplace and their families well as the local community and society at large. Also, Matthews (1993) has defined social and environmental disclosure as organizations voluntarily disclosing quantitatively and qualitatively about their CSR activities to inform their stakeholders. Companies engage in CSR activities and its disclosure due to some motivations.

Many motivational elements explain the importance and benefits of the company's participation in CSR. These intentions are broadly classified into strategic and ecological (Lantos, 2001), economic objectives and moral objectives as CSR participation (Hillman and Keim, 2001; Joyner and Payne, 2002). Both scientific evidence (Margolis and Walsh, 2003) and consumer feedback (McWilliams and Siegel, 2001) have given signals to companies involved in CSR activities and the 
company's performance improvement can reward its publicity. In this regard, the companies engaged in CSR activities and its publication can build relationships with different stakeholders (McWilliams \& Siegel, 2001), thus reducing its business risk (Bouatine-Dufresne and Savaria, 2004). For this reason, the strategic value of CSR is increasingly being recognized (Porter and Kremer, 2003).

Researchers differentiated to define CSR (Obaloha, 2008: 539; Votaw and Launche, 1973; Preston and Post, 1975; Makower, 1994). For example, Bowen (1953) defines CSR as corporate decision making for a community's bias. Frederick (1960) explains CSR use community resources, enhances the benefits of society and social equities besides corporate profits and corporate owners. Based on Elkington (1997) theory, CSR is an idea of corporate responsibility considering the interests of customers, employees, shareholders, communities, and all aspects of their actions. These obligations are widely applicable to exceed the obligation set by the law. Carroll (1999) mentions that CSR has economic responsibility, law, ethics and the charitable organization. According to Carroll (1999), CSR has been described as a pyramid, where economic responsibility is the key to corporate responsibility, followed by the responsibility of law, ethics and the last is charity (Carroll, 1999: 264). Dashrud (2006) reviewed thirty-seven definitions that investigators often use according to CSR definition; He concluded that five levels are often used in the CSR system; Environmental levels, social levels, economic levels, stakeholder levels, and charity levels.

Bala S.K and Yusuf (2003: 31-43) conduct a test study to assess the current situation of Corporate Environmental Report by the Public Limited Company (PLC) listed in Bangladesh. They found that only $10.4 \%$ of the listed PLC included an environmental report in their annual report. Khan, H. et al (2009), representing their criticisms of the CSR system by the public limited company (PLC) listed in Bangladesh in their annual report. They have not found satisfactory CSR reporting practices. In most cases, sample companies use Director Reports to publish CSR.

Warnakulasooriya \& Jayarathne (2008: 408-419) did a study to assess the directors' attitude about CSRs in Sri Lanka. They see that a significant portion of the manager's favorable attitude towards CSR and the different business managers have similar ideas. Most of them believe that CSR activities increase their company's long-term profitability. Literature acknowledges that the CSR system is separate from country to country (Adams, Hill and Roberts, 1998) and developed and developing countries (Imam, 2000).

\section{Methodology}

This study is based on a systematic process that ensures its trustworthiness in research. To support the research findings, secondary data are used in an empirical quantitative fashion. The main data sources are banks' annual reports because most developing and developed countries widely use annual reports as one major source (among others) of reliable information (Akhtaruddin, 2005; Catasús, 2008; Chau and Gray, 2010). Empirical studies (Naser and Nuseibeh, 2003; Al-Razeen and 
Karbhari, 2004) show that the annual report is a formal source of information in developing countries.

However, the annual report is not the only source: shareholders can also retrieve information through either direct sources or media publications. In this regard, the study relies on annual reports as a major source of data. This study also examines a single country because Bangladesh's sociopolitical and economic environment is different from those of other countries in the Asian region. Moreover, there is very little work found in addressing the propensity of CSR expenditures in the time horizon and its proximate causes.

\subsection{Data}

The study selects the sample consisting of thirty-two (32) Bangladeshi commercial banks from 2011 to 2015 . The dataset is a balanced panel where all the observations are accumulated for the analysis. This panel data is cross-sectional dominance as the cross-section number is more than the period $(n>t)$. From this table, it can be seen that out of 6 state-owned commercial banks (SCBs), 4 SCBs have been taken as samples. In private commercial banks (PCBs), 28 out of 39 listed banks have been taken as samples. All the samples banks will be used for evaluating their performances under various conditions. Thus the expected banks-year observations are a total of 160 .

Table 1: Sample Description

\begin{tabular}{|l|c|c|c|}
\hline Types of Banks & Population & Sample & Percentage of samples \\
\hline SCBs & 6 & 4 & $12.5 \%$ \\
\hline PCBs & 39 & 28 & $87.5 \%$ \\
\hline TOTAL & $\mathbf{4 5}$ & $\mathbf{3 2}$ & $\mathbf{1 0 0 \%}$ \\
\hline
\end{tabular}

Source: Research data (Year2010 - 2015), Authors' computations.

\subsection{Model specification}

Most of the research conducted earlier based on the CSR activities enumerates the scenarios and bank disclosures practice and the level of investment. Sharif and Sarker (2011) examine the CSR practices in the banking sector of Bangladesh.

They draw a picture of the CSR investment in society, prioritizing the sectoral contribution. However, this study tries to find out the proximate cause that influenced the CSR investment in society. The model of the study is developed as:

$\operatorname{CSRE}_{i t}=\operatorname{CSRE}_{i t}(-1)+N P L T L_{i t}+S I Z E_{i t}+O E T A_{i t}+A G E_{i t}+O W N S_{i t}+\varepsilon_{i t}$

Here: $\mathrm{i}=1,2,3 \ldots ; 32 \quad \mathrm{n}=32$ (banks) $\mathrm{t}=2010, \ldots 2014 \quad \mathrm{t}=5$ (years) 
Where: CSRE represents the proportional of CSR, CSRE (-1) represents the one year lag effect of CSRE; NPLTL represents Non-performing loan to total loan; SIZE represents log of total assets; OETA represents the owner's equity to total assets, AGE represents Years of bank experience from its incorporation; and OWNS represents the ownership structure on banks.

The data set's nature is panel data where 32 commercial banks and a time series of fifteen (5) years. Several studies (Baltagi, 2001; Hsiao, 1986) found that panel data controls individual heteroskedasticity and reduces multicollinearity and biased estimation. Our study examines the heteroskedasticity (White) test, which accepts the null hypothesis at $1 \%$ significance level and tests serial correlation (Breusch-Godfrey serial correlation LM test), which is also significant at $1 \%$ level. These diagnoses result restrict in using the ordinary least square (OLS) method in the model. The dataset is restricted due to heteroskedasticity, cross-sectional correlation and firstorder autoregressive correlation AR (1) in the error terms. The Prais Winsten Regression (PCSE) methods can overcome the limitation of the existing data set (Wooldridge, 2006). This method allows cross-sectional correlation and heteroskedasticity across panels. In our study, we interpret the results based on PCSE methods and prove the model's robustness.

The study expects that the independent variables' effect can be derived either positive or negative based on the statistical significance. Figure 2 below is assumed to give the specific impact on the propensity to CSR expenditure that will become out by further analysis.

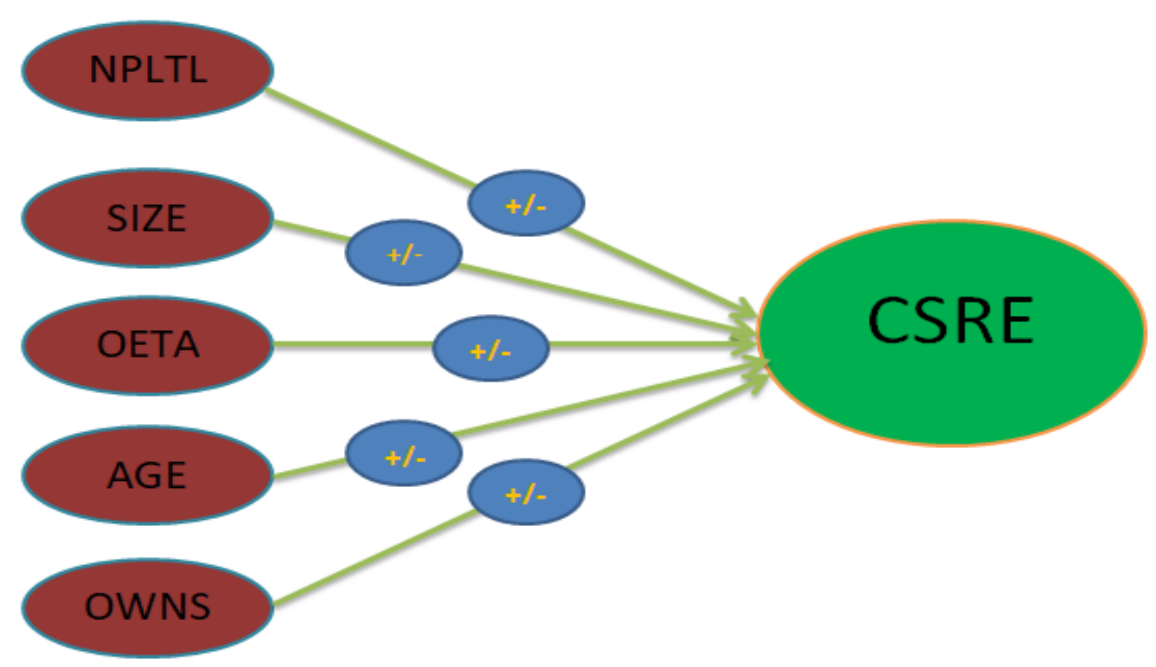

Figure 2: Factors affecting Bank CSR Expenditures 


\section{Empirical Analysis}

\subsection{Descriptive Statistics}

The descriptive statistics presented in Table 4 were constructed using SPSS 17 for thirty-two (32) commercial banks from 2010 to 2014. Table 2 represented the descriptive statistics of thirty-two (32) commercial banks with the most recent five (5) years data from 2010 to 2014 . The study showed the mean, standard deviation, minimum and maximum value of the observed variables. It is found that the respondent variable CSRE has a mean value of 6.1666 with a standard deviation of 1.238. It demonstrates that some banks are not inclined to distribute their profit in CSR activities as the minimum value implied zero (0). In the case of NPLTL, it is found that the average value is 0.0552 with minimum and maximum value of 0.0073 and 0.3309 , respectively. It is revealed that government-owned banks have a high non-performing loan in comparison with privately-owned banks. Bank size is represented by the $\ln$ (total assets) used to resize the large value into a small amount. It is found that the mean value is 11.9519 with a standard deviation of 0.5851 . It indicates that the sample banks are homogeneous in terms of their total assets as they have little deviations in their maximum and minimum values.

Table 2: Descriptive Statistics

\begin{tabular}{|c|c|c|c|c|c|}
\hline Variable & Obs & Mean & Std. Dev. & Min & Max \\
\hline CSRE & 160 & 6.1666 & 1.2380 & 0.0000 & 9.8057 \\
\hline NPLR & 160 & 0.0574 & 0.0552 & 0.0073 & 0.3309 \\
\hline SIZE & 160 & 11.9519 & 0.5851 & 10.9090 & 13.7486 \\
\hline OETA & 160 & 0.0864 & 0.0226 & 0.0180 & 0.1543 \\
\hline AGE & 160 & 21.4063 & 9.8666 & 9 & 43 \\
\hline OWNS & 160 & 0.1875 & 0.3915 & 0 & 1 \\
\hline
\end{tabular}

The shareholder's influence is represented by the OETA, which shows that the average value is 0.0864 with a standard deviation of 0.0226 . The variable AGE is calculated by the period of the inception date to the examination year. It is found that the average year of banks is 22 year, where the maximum and minimum year of operation is nine (9) years and 43 years. The ownership of banks is presented as a dummy variable where " 1 " indicates private-owned banks and " 0 " for otherwise.

\subsection{Univariate Analysis}

In the univariate analysis, the correlation coefficient assesses the strength of the relationship between two variables, but it does not tell how much of the variance of the dependent variable will be explained by several independent variables (Sekaran, 1992). Also, Patton and Zelenka, (1997) argued that univariate analysis could overestimate the significant overall explanatory power of independent variables. 
The Pearson correlation coefficient matrix is performed and presented below to examine the association between various variables utilized in this study.

"Correlation coefficients measure the strength of associations or relationships between two variables" (Field, 2009). The strength of coefficient is varieties from minus one (-1) to plus one (+1). This study operates Pearson correlation matrixes to detect the strength of the relationships between variables and notice the issue of Multicollinearity between variables. Multicollinearity occurs when two or more independent variables can clarify the dependent variable well, but they may be significantly correlated. If Multicollinearity exists in an equation, it could be hard to decide the independent variables' separate effects on the dependent variable (Cooper and Schindler, 2008). The existence of Multicollinearity in a model creates it incredible to identify the impact of individual predictor variables on the dependent variable (De Fusco et al., 2007). Alsaeed (2005) agreed that the correlation matrices are considered great tools to understand the relationship between predictors better. Multicollinearity implies that a perfect linear relationship exists between one or two the predictors. It can be biased the regression model when multicollinearity is present. The inclusion of such variables in the equation could decline the analysis by inflating the size of error terms (Tabachnick and Fidell, 2007). According to Cooper and Schindler (2008), the two variables are considered significantly correlated at 0.8 or a greater level. The degree of correlation is considered high and causes a Multicollinearity problem if it exceeds 0.80 or 0.90 (Field, 2009). The study conducted Pearson's correlation test which measures the degree of change between cause and effect relationship. It removes the unit problem of the covariance.

The formula of correlation is:

$$
\operatorname{corr}(X, Y)=\frac{\operatorname{cov}(X, Y)}{\sqrt{\operatorname{var}(X) \operatorname{var}(Y)}}=\frac{\sigma_{X Y}}{\sigma_{X \sigma_{Y}}}
$$

The variables are said to be uncorrelated if $\operatorname{corr}(\mathrm{X}, \mathrm{Y})=0$.

The range of the coefficient of correlation is between -1 and +1 .

It is expressed as:

$$
-1 \leq \operatorname{corr}(\mathrm{X}, \mathrm{Y}) \leq 1 \text { (correlation inequality) }
$$

Table 3 showed the Pearson's correlation matrix indicating the rate of change between the explained and explanatory variables. It has been found that bank Size (SIZE) has a positive and statistically significant correlation with explained variable CSRE at one (1\%) percent level with a coefficient of 0.232. Moreover, variables NPLR, OETA, AGE, and OWNS variables have a negative correlation with coefficients of $-0.169,-0.176,-0.118$ and -0.246 , with CSRE and are statistically significant $(\mathrm{P}<0.01, \mathrm{P}<0.05)$. It is also revealed that there is no multicollinearity problem in the model which Field, (2009) support. 
Table 3: Pearson's Correlation Matrix

\begin{tabular}{|c|c|c|c|c|c|c|}
\hline & CSRE & NPLTL & SIZE & OETA & AGE & OWNS \\
\hline CSRE & 1 & $-.169^{*}$ & $.232^{* *}$ & $-.176^{*}$ & -.118 & $.246^{* *}$ \\
\hline NPLR & & 1 & $.599^{* *}$ & $-.401^{* *}$ & $.592^{* *}$ & $-.161^{*}$ \\
\hline SIZE & & & 1 & $-.271^{* *}$ & $.702^{* *}$ & -.002 \\
\hline OETA & & & & 1 & -.117 & -.059 \\
\hline AGE & & & & & 1.000 & $-.231^{* *}$ \\
\hline OWNS & & & & & 1 \\
\hline
\end{tabular}

\subsection{Multivariate Analysis}

In the model, the lag effect of corporate social responsibility expenditure CSRE $(\mathrm{t}-1)$ have a positive impact and is statistically significant $(\mathrm{p}<0.01)$. It implies that the previous year expenditure constitutes a culture to expend more on CSR activities. Though it is one kind of advertisement in society, it plays an active role to support the weaker section by their donation. It is found that banks tried to focus their activities on the annual reports by showing their philanthropic activities. The stakeholder model strongly advocates CSR activities as they assume the welfare of the society virtually ensures the firms' sustainability in the long run.

In the case of a non-performing loan rate, it is found that there is a negative effect on bank CSR expenditure (CSRE). The non-performing loan rate is the proxy for bank credit risk, which indicates the lower bank performance. In this study, it is found that a higher non-performing loan rate gradually declines the intensity of CSR expenditure (CSRE), but the cause cannot be concluded with a direct cause and effect relationship. The proximate cause initiated with the declining response of profitability concerning higher non-performing loan (NPLR), which discourage banks by laws and customs in investing more in CSR activities. The study revealed that the rate of change between NPLR and CSRE is -5.7555 , which validates the concept of "higher profit stimulates higher CSR expenditure."

The total assets of the banks represent the size of the bank. The study found that SIZE positively impacted bank CSR investment and significant at $1 \%$ level. It means that banks with more assets or big size are involved more in CSR activities and small-sized banks have the reverse effect. The cause may be the higher profit earned by the large banks involved in more philanthropic activities for creating goodwill in the market.

The shareholder's influence is proxied by the owner's equity to total assets (OETA), indicating the proportion of shareholders claim on total assets.

The shareholder's theory establishes the rights and incentives assured for the shareholders' interest, not for the stakeholders. The contradiction comes to the point where profit maximization is not tempted by wealth maximization. Shareholders 
theory restricts investing more profit in CSR activates as shareholders benefit declines.

Therefore, higher shareholders influence in the capital structure demotivates banks in higher CSR expenditures.

Table 4: CSR Expenditure (CSRE)

\begin{tabular}{|c|c|c|c|c|}
\hline Variable & Coefficient & Std. Error & t-Statistic & Prob. \\
\hline CSRE(-1) & 0.4948 & 0.0898 & 5.5117 & $0.0000 * * *$ \\
\hline NPLR & -5.7555 & 1.8743 & -3.0707 & $0.0026 * * *$ \\
\hline SIZE & 0.9542 & 0.2378 & 4.0119 & $0.0001 * * *$ \\
\hline OETA & -11.9780 & 4.5077 & -2.6572 & $0.0090 * * *$ \\
\hline AGE & -0.0263 & 0.0125 & -2.1148 & $0.0365^{*}$ \\
\hline OWNS & 0.0342 & 0.1782 & 0.1922 & 0.8479 \\
\hline $\mathbf{C}$ & -6.3410 & 2.3761 & -2.6687 & $0.0087 * * *$ \\
\hline R-squared & $57.96 \%$ & \multicolumn{2}{|c|}{ F-statistic } & 27.56 \\
\hline Adjusted R-squared & $55.85 \%$ & \multicolumn{2}{|c|}{ Prob(F-statistic) } & 0.00 \\
\hline
\end{tabular}

$(* * *)$ indicates significance at $1 \%$ level; $(* *)$ indicates significance at $5 \%$ level and $(*)$ indicates significance at $10 \%$ level. The reported p-values are all two-tailed except intercept.

Banks' age is the year of experience counted from the inception date of the operation to the targeted period. It is found that aged banks are reluctant to spend more on social welfare. The reason is not that the experienced banks willingly ignore their donation to the society, but they are somehow bound to invest less for the public interest. In Bangladesh, most experienced banks are state-owned commercial banks and have high non-performing loans that undermine their profits day by day. The propensity to higher risk-taking behavior and less profitability discourage more increased investment in social welfare. Therefore, the relevance of the experienced banks negatively impacts CSRE as valid and statistically significant $(\mathrm{P}<0.05)$.

The banks' ownership is represented by the dichotomous variable where "1" represented by the private commercial banks and " 0 " otherwise. It is assumed that private commercial banks engaged more in CSR activities than state-owned commercial banks. The study found that private commercial banks invest more in CSR related works than state-owned commercial banks but statistically insignificant. Based on the above results, the study found that the factors affect the CSR expenditures used as stimuli of CSR activities. 


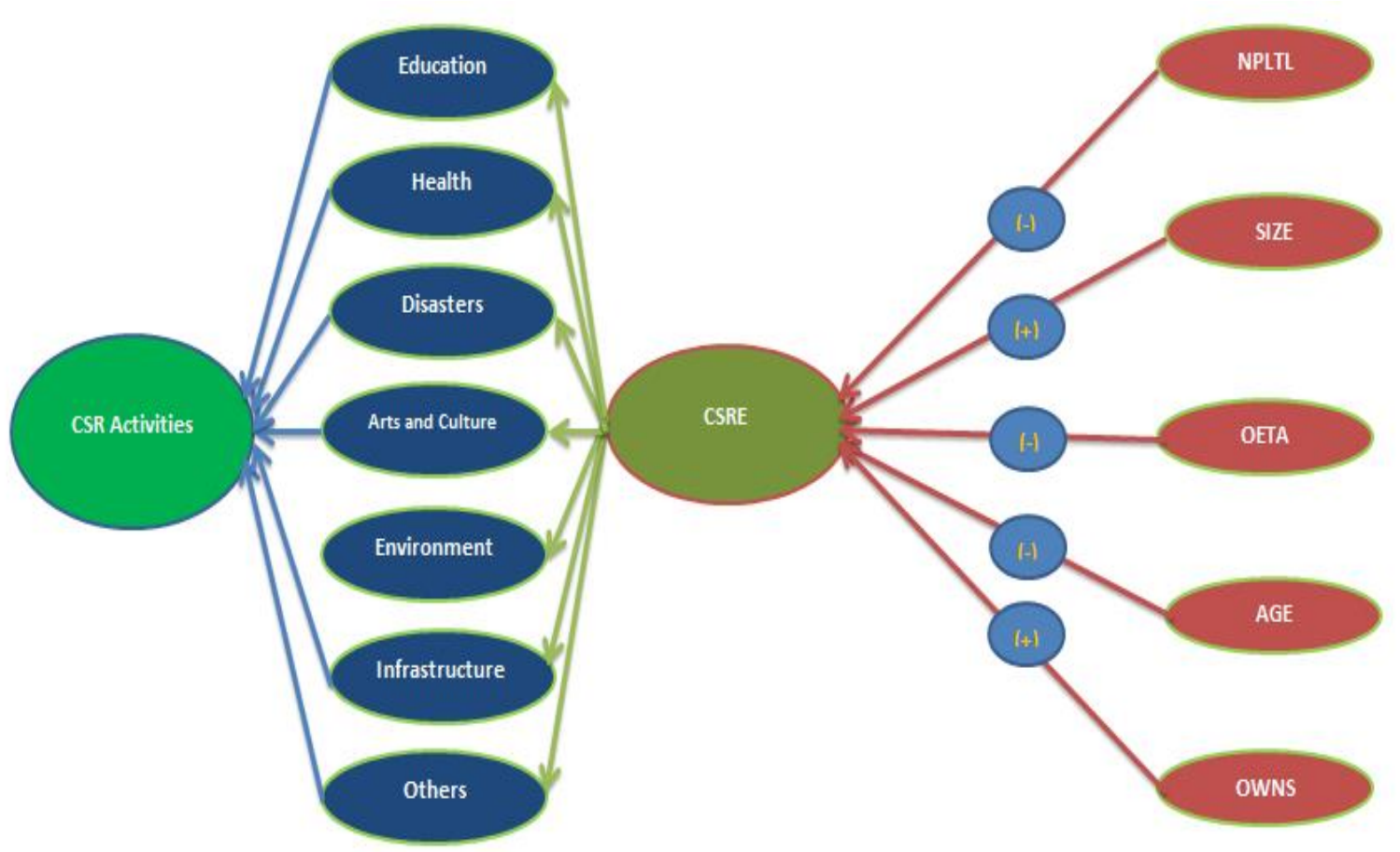

Figure 3: Factors influencing CSR expenditures

Therefore, the corporate social responsibility expenditure model depends on the factors that are positively or negatively affect repressors and are also statistically significant. The refined model is:

$\operatorname{CSRE}_{\mathrm{i}, \mathrm{t}}=0.4948 \operatorname{CSRE}_{\mathrm{i}, \mathrm{t}-1}-5.7555 \mathrm{NPLR}_{\mathrm{i}, \mathrm{t}}+0.9542 S I Z E_{\mathrm{i}, \mathrm{t}}-11.9780$ OETA $_{\mathrm{i}, \mathrm{t}}-0.0263 \mathrm{AGE} \mathrm{i}_{\mathrm{i}, \mathrm{t}}-6.3410$

\section{Conclusions and Policy Recommendations}

The banking sector of Bangladesh has been playing a significant role in the economy. In capital formation and serving the financial needs of the people, business \& trade, and industrial sector, the banking industry performs the pioneering role in any other economy. Besides, its importance in generating employment opportunities, encouraging savings and investment, promoting foreign exchange is outstanding. However, the banking sector of Bangladesh can be characterized as commercial and rarely concerned about the poor. As a result, a significant portion of the population is still deprived of financial services, like banking, despite having a huge demand for it. Besides, the banking sector has been concerned about profit maximization but not in social issues, like people and the planet. So, the country lacks the proper banking system.

The study indicates that poor people are the underprivileged part of society, especially due to their financial inabilities. Besides, they lag in social matters, like education, health, communication, art and culture and many more, and run opposite to the sustainable development concept. They have much potential but lack of 
opportunities to utilize it. Though the country has a well-structured banking sector, due to its commercial attitude, the poor's demands are always kept aside, which is badly affecting the country's overall development. In this circumstance, the banking sector should concentrate more on this underprivileged part. 'Responsible Banking System' suggests that the banking system has to serve the demands of the targeted group of consumers but in socially responsible manner. Maximizing profit is a concern for the bank but being concerned about the people and planet is more important. In Bangladesh's perspective, the 'Responsible Banking System' could be a better option to serve the more significant portion of the population.

However, the banking structure of Bangladesh needs to be more concerned about the underprivileged part and be prompt and transparent in social concerns.

Though the banking sector has been found concerned in social matters, it is quite insignificant for ensuring the country's overall development. So, the banking sector can evolve from commercial banking to responsible banking.

Besides, the government should take initiatives as well as the banks should come up with a proper CSR strategy.

\section{References}

[1] Adams, C. A., Hill, W.Y. and Roberts, C. B. (1998). Corporate social reporting practices in Western Europe: legitimating corporate behaviour? British Accounting Review, 30(1), pp. 1-21. (doi: 10.1006/bare.1997.0060)

[2] Akhtaruddin, M.. (2005). Corporate mandatory disclosure practices in Bangladesh. The International Journal of Accounting. 40. 399-422. 10.1016/j.intacc.2005.09.007.

[3] Al-Razeen, A. and Karbhari, Y. (2004). Users' perception of corporate information in Saudi Arabia: An empirical analysis. International Journal of Commerce and Management. 14. 41-57. 10.1108/10569210480000183.

[4] Alsaeed, K. (2005). The association between firmspecific characteristics and disclosure: The case of Saudi Arabia. The journal of American Academy of business, 7(1), 310-321.

[5] Arora, R. (2010). Structure and Reform of Corporate Governance in the United Kingdom in Relation to the Shareholder Versus the Stakeholder Theory. Available at SSRN: https://ssrn.com/abstract=1683987 or http://dx.doi.org/10.2139/ssrn.1683987

[6] Bagnoli, M. and Watts, S. (2003). "Selling to socially responsible consumers: Competition and the private provision of public goods," Journal of Economics and Management Strategy, 12: 419-445.

[7] Bala, S. K. and Yusuf, M. A. (2003). Corporate environmental reporting in Bangladesh: a study of listed public limited companies. Dhaka University Journal of business studies, 24(1), 31-45.

[8] Baltagi, B. (2001). Econometric Analysis of Panel Data, 2nd ed., John Wiley and Sons, Chichester. 
[9] Barnea, A., Rubin, A. (2010). Corporate Social Responsibility as a Conflict Between Shareholders. J Bus Ethics 97, 71-86 (2010). https://doi.org/10.1007/s10551-010-0496-z

[10] Baron, D. (2001). "Private politics, corporate social responsibility and integrated strategy," Journal of Economics and Management Strategy, 10: 7-45.

[11] Blowfield, M. and Frynas, J.G. (2005). Setting New Agendas: Critical Perspectives on Corporate Social Responsibility in the Developing World. International Affairs, 81, 499-513.

[12] Bouatine-Dufresne, F. and Savaria, P. (2004). 'Corporate Social Responsibility and Financial Risk', Journal of Investing 13, 57-66.

[13] Bowen, R. H. (1953). Social responsibilities of the businessman; New York, Harper

[14] Capasso, A. (2004). Stakeholder Theory and Corporate Governance: The Role of Intangible Assets. Corporate Finance: Governance.

[15] Carroll, A.B. (1999). Corporate Social Responsibility: Evolution of a Definitional Construct. Business \& Society ;38(3):268-295. doi:10.1177/000765039903800303

[16] Catasús, B. (2008). In search of accounting absence. Critical Perspectives on Accounting, 19(7), 1004-1019.

[17] Chau, G. and Gray, S. (2010). Family ownership, board independence and voluntary disclosure: Evidence from Hong Kong. Journal of International Accounting, Auditing and Taxation. 19. 93-109. 10.1016/j.intaccaudtax.2010.07.002.

[18] Cooper, D. and Schindler, P. (2008). Business research methods (10th ed.). New York, McGraw-Hill/Irwin.

[19] Votaw, D. and Sethi, S.P. (1973). The corporate dilemma: Traditional values versus contemporary problems. Englewood Cliffs, NJ: Prentice Hall. pp: 1145.

[20] Dashrud, A. (2006). How Corporate Social Responsibility is Defined: an Analysis of 37 Definitions. Wiley InterScience, John Wiley and Sons, Ltd and ERP Environment.

[21] DeFusco, R. A. (2007). Quantitative investment analysis, Hoboken N.J. : Wiley

[22] Elkington, J. (1997). Cannibals with Forks: The Triple Bottom Line of 21st Century Business. Capstone, Oxford.

[23] Field, A. (2009). Discovering Statistics Using SPSS. 3rd Edition, Sage Publications Ltd., London.

[24] Frederick, W.C. (1960). The Growing Concern over Business Responsibility. California Management Review. 1960;2(4):54-61. doi:10.2307/41165405

[25] Freeman, R. E. (1984). Strategic management: A stakeholder approach. Boston: Pitman

[26] Gamerschlag, R., Möller, K. and Verbeeten, F. (2010). Determinants of voluntary CSR disclosure: Empirical evidence from Germany. Review of Managerial Science. 5. 233-262. 10.1007/s11846-010-0052-3. 
[27] Gray, R., Javad, M., Power, D.M., Sinclair, C.D. (2001) Social and environmental disclosure and corporate characteristics: a research note and extension. J Bus Finance Account 28(3 and 4):327-356

[28] Gray, R., Kouhy, R. and Lavers, S. (1995). Corporate social and environmental reporting: a review of the literature and a longitudinal study of UK disclosure. Account Audit Account J 8(2):47-77

[29] Gray, R., Owen, D. L. and Maunders, K. (1987). Corporate social reporting: accounting and accountability. Hemel Hempstead, Herts, Prentice-Hall International

[30] Gray, R., Owen, D. and Maunders, K. (1986). Corporate social reporting: The way forward?. 6-8.

[31] Guthrie, J. and Parker, L. (1990). Corporate social disclosure practice: A comparative international analysis. Advances in Public Interest Accounting, 3, 159-175.

[32] Hackston, D. and Milne, M. (1996). Some Determinants of Social and Environmental Disclosure in New Zealand Companies. Accounting, Auditing \& Accountability Journal. 9. 77-108. 10.1108/09513579610109987

[33] Harrison, J. and Wicks, A. (2013). Stakeholder Theory, Value, and Firm Performance. Business Ethics Quarterly. 23. 97-125. 10.5840/beq20132314.

[34] Heslin, P. A. and Ochoa, J. D. (2008). Understanding and Developing Strategic Corporate Social Responsibility. Organizational Dynamics, Vol. 37, pp. 125-144, Available at SSRN: https://ssrn.com/abstract=1149001

[35] Hillman, A. J. and Keim, G. D. (2001). 'Shareholder Value, Stakeholder Management, and Social Issues: What's the Bottom Line?', Strategic Management Journal 22, 125-139

[36] Hsiao, C. (1986). Analysis of panel data. Cambridge University Press.

[37] Imam, Shahed. (2000). Corporate Social Performance Reporting in Bangladesh. Managerial Auditing Journal. 15. 133-142. 10.1108/02686900010319384.

[38] Joyner, B. E. and Payne, D. (2002). 'Evolution and Implementation: A Study of Values, Business Ethics and Corporate Social Responsibility', Journal of Business Ethics 41, 297-311.

[39] Kent, P. and Chan, C. (2009). Application of stakeholder theory to corporate environmental disclosures. Corporate Ownership \& Control, 7(1-3), 394410. https://doi.org/10.22495/cocv7ilc3p6

[40] Kent, P. and Chan, C. (2003). "Application of stakeholder theory to the quantity and quality of Australian voluntary corporate environmental disclosures", working paper, UQ Business School, University of Queensland Australia, Brisbane ....activities (Capasso, 2004).

[41] Khan, H., Halabi, A.K. and Samy, M. (2009). Corporate Social Responsibility (CSR) Reporting: A Study of Selected Banking Companies in Bangladesh. Social Responsibility Journal. 5. 344-357. 10.1108/17471110910977276. 
[42] Konz, G. N. P. and Ryan, F. X. (1999). Maintaining an organizational spirituality: No easy task. Journal of Organizational Change Management, 12(3), 200-210. https://doi.org/10.1108/09534819910273865

[43] Lantos, G.P. (2001). The Boundaries of Strategic Corporate Social Responsibility. Journal of Consumer Marketing, 18, 595-632.

http://dx.doi.org/10.1108/07363760110410281

[44] Makower, J. (1994). Beyond the Bottom Line: Business for Social Responsibility. Tiden Press, Inc., New York.

[45] Margolis, J. D. and J. P. Walsh: 2003, 'Misery Loves Companies: Rethinking Social Initiatives by Business', Administrative Science Quarterly 48, 268-305.

[46] Matthews, M. R. (1993). Socially responsible accounting. London: Chapman and Hall

[47] McGuire, J.B., Schneeweis, T., Branch, B. (1990).Perceptions of Firm Quality: A Cause or Result of Firm Performance. Journal of Management. 1990;16(1):167-180. doi:10.1177/014920639001600112

[48] McWilliams, A. and Siegel, D. (2001). 'Corporate Social Responsibility: A Theory of the Firm Perspective', Academy of Management Review 26, $117-$ 127.

[49] Naser, K. and Nuseibeh, R. (2003). RETRACTED: User's perception of corporate reporting: evidence from Saudi Arabia. The British Accounting Review. 35. 129-153. 10.1016/S0890-8389(03)00015-5.

[50] Obaloha, M. (2008). Beyond Philanthropy: Corporate Social Responsibility in The Nigerian Insurance Industry. Social Responsibility Journal, Vo. 4, No. 4, Emerald Group Publishing Limited.

[51] Patton, J. and Zelenka, I. (1997). An empirical analysis of the determinants of the extent of disclosure in annual reports of joint stock companies in the Czech Republic, European Accounting Review, 6, issue 4, p. 605-626, https://EconPapers.repec.org/RePEc:taf:euract:v:6:y:1997:i:4:p:605-626.

[52] Porter, M. and Kramer, M. (2003). The Competitive Advantage of Corporate Philanthropy. Harvard business review. 80. 56-68, 133.

[53] Preston, L.E. and Post, J.E. (1975). Private management and public policy: The principle of public responsibility. Englewood Cliffs, NJ: Prentice-Hall.

[54] Roberts, J. and Scapens, R. (1985). Accounting systems and systems of accountability: understanding accounting practices in their organizational contexts. Accounting, Organizations and Society, 10(4):443-456

[55] Sekaran, U. (1992). Research Methods for Business: A Skill-Building Approach. New York: John Wiley \& Sons, Inc.

[56] Sharif M. J. and Sarker, N. (2011). Corporate Social Responsibility: A focus on the banking sector of Bangladesh. Journal of Banking \& Financial Services, Vol. 5, No. 2.

[57] Swift, T. (2001). Trust, reputation and corporate accountability to stakeholders. Business Ethics: A European Review 10(1):16-26

[58] Tabachnick, B. G. and Fidell, L. S. (2007). Using multivariate statistics (5th ed.). Allyn \& Bacon/Pearson Education. 
[59] Utting, P. (2002). The Greening of Business in Developing Countries. Rethoric, Reality and Prospects. London, New York, Zed Books, UNRISD.

[60] Van der Laan S. J., Adhikari, A. and Tondkar, R. (2005). Exploring differences in social disclosures internationally: A stakeholder perspective. Journal of Accounting and Public Policy. 24. 123-151. 10.1016/j.jaccpubpol.2004.12.007.

[61] Waddock, S.A and Graves, S.B. (1997). Quality of Management and Quality of Stakeholder Relations: Are They Synonymous? Business \& Society. 1997;36(3):250-279. doi:10.1177/000765039703600303

[62] Warnakulasooriya, B. and Jayarathne, P. (2008). Managers' Attitudes Towards Corporate Social Responsibility: With Special Reference to Service Industry In Sri Lanka.

[63] Williams, P. F. (1987). The legitimate concern with fairness. Accounting, Organizations and Society, 12(2):169-1

[64] Wooldridge, J.M. (2006) Introductory Econometrics: A Modern Approach. 3rd Edition, Thomson/South-Western, Mason.

[65] World Business Council for Sustainable Development (WBCSD), (1998). Corporate Social Responsibility, Geneva, Switzerland, ISBN No. 2-94-024003-5, https://growthorientedsustainableentrepreneurship.files.wordpress.com/2016/07/csr-wbcsd-csr-primer.pdf 